\title{
HEART OVER THE HEAD: SCIENCE TEACHERS' INFLUENCE IN DEVELOPING SELF-AWARENESS AMONG THEIR ADOLESCENT STUDENTS
}

\author{
Debjani Bhattacharya ${ }^{1}$ \\ ${ }^{1}$.Doctoral Scholar;
}

Department of Teacher Education, The West Bengal University of Teachers' Training, Education Planningand Administration 25/3 Ballygunge Circular Road, Kolkata, W.B. - 700019, India.

\author{
Kaustuv Bhattacharyya ${ }^{2} *$ \\ ${ }^{2}$.Assistant Professor;
}

Department of Teacher Education, The West Bengal University of Teachers' Training, Education Planning and Administration [erstwhile David Hare Training College];

25/3 Ballygunge Circular Road, Kolkata,W.B. - 700019, India.

\author{
AbhijitGuha $^{3}$ \\ ${ }^{3}$.Associate Professor, \\ Department of Education, \\ Ramkrishna Mission Sikshana Mandir, \\ Belur Math, \\ Howrah, \\ W.B. -711202. \\ *Corresponding Author
}

Article DOI: https://doi.org/10.36713/epra5410

\begin{abstract}
Self-awareness, at any stage, is very important in an individual's life as it includes the recognition of cognitive-and social-, as well as emotional intelligence within the self.This study was conducted with an aim to assess 'teaching with the head' and 'teaching with heart' which one is more powerful in developing self-awareness among their students.The descriptive survey method was used for the 405 students and 58 teachers of Kolkata (South Kolkata and North Kolkata), selected through a random sampling technique. Two standardized questionnaires were prepared for assessing the nature of a student's selfawareness and teacher's teaching methods while t-tests were conducted to test the hypotheses. Results indicate that the methods of developing self-awareness must be influenced by the characteristics of the teaching with heart and during adolescence - students become very much aware of themselves which, in turn, emphasizes the requirement of proper development of their self-awareness. Therefore, a major contribution of this study may provide a platform to isolate some of the factors which affect the self-awareness of the adolescent students.
\end{abstract}

KEYWORDS: Self-awareness, adolescent student,teaching with head,teaching with heart, science teacher. 


\section{INTRODUCTION}

"If your head tells you one thing, and your heart tells you another,

before you do anything decide first whether you have a better head

or a better heart."

\section{- $\quad$ Albert Einstein}

In the present super complex world only the bookish knowledge is not enough to bring all-round development within a student. So the basic aims of the education system sometimes remain unattained. Some factors, which are not included in the textbook play important roles in the development of children. Such an important factor is self-awareness.

Now if we search the answer of the question 'what is self-awareness we will get different answers from different fields of study. According to Socrates, 'self' means the knowledge of oneself and according to him 'self-awareness is' a prerequisite to a deeper understanding of life'.'Bodhidharma' utters that, 'Buddha means awareness, the awareness of body and mind that prevents evil from arising in either.' The Buddha said that,' Let none find fault with others, let none see the omissions and commissions of other. But let one se one's own acts done and undone.According to psychology, 'self-awareness is a psychological state in which oneself becomes the focus of own attention.' Psychologist Daniel Goleman, in his book 'Emotional Intelligence' opined about self-awareness that "Knowing one's internal states, preferences, resources and intuitions."

Self-awareness involves 'tuning in' to feeling and thoughts. It helps students to know how other people see them. Self-awareness is an important skill for the students to recognize his/her strengths and weaknesses, recognize errors in school works, can understand and talk about his feelings, recognize other people's needs and feelings. A student can understand how his/her behavior affects others. He/she will be better at self-monitoring and self-reflection. Selfawareness is developed through practices in focusing one's attention on the details of one's personality and behavior. It cannot be learned by reading a book. When we read a book we focus our ideas on the conceptual ideas included in the book but intellectual understanding can only develop by reading with selfawareness. It is like learning to dance. When we learn to dance we must pay attention to how and when our feet move our hands and body motion and position of other dancers etc.

The students spend a huge amount of time with their teachers in a classroom situation. So knowingly or unknowingly teachers play a vital role in developing student's self-awareness. Sometimes the teachers apply different methods for developing student's selfawareness effectively. By adopting different methods of teaching they can perform their job.

Now, during the adolescence period, the students face different kinds of problems closely related to their self-awareness. At this stage, the students are required to adapt and adjust childhood behaviors to culturally acceptable adult forms. Adolescence is more than a transition; it is a stage of development in its own right, just like childhood or adulthood. A teacher can solve the problem and guide them to a better and prosperous future.

Now there are different ways of teaching. Teaching with head means mental activities including thinking; remembering, learning and using appropriate language. When we apply this approach to learning and teaching, we focus on the understanding of information and concepts only. Teaching with heart means emotions are at the heart of what teachers do and the reason they do it.

\section{OBJECTIVES}

The study was conducted with the following objectives:-

Objective 1: Observing whether there is any difference between the science teachers 'who teach with the head' and 'who teaches with heart' in developing selfawareness among their students.

Objective 2: Estimating whether there is any difference between male science teachers teaching with head and male science teachers teaching with heart in developing self-awareness among their students.

Objective 3: Observing whether there is any difference between female science teachers teaching with head and female science teachers teaching with heart in developing self-awareness among their students.

\section{HYPOTHESES}

In light of the objectives of the study, the following hypotheses were formulated:

$\mathrm{H}_{0} 1$ :There is no significant difference between the two groups of science teachers 'who teach with the head' and 'who teach with heart' in developing selfawareness among their students.

$\mathrm{H}_{0}$ 2: There is no significant difference between the male science teachers teaching with head and male science teachers teaching with heart in developing selfawareness among their students.

$\mathrm{H}_{0} 3$ : There is no significant difference between the female science teachers teaching with head and female science teachers teaching with heart in developing selfawareness among their students. 


\section{MATERIALS AND METHODS}

The study implemented a Descriptive Survey Research Design to study theimpact of the methods employed by the science teachers for developing selfawareness among their students.

Table 1: Table for analysis of the status of the dependent variablewith respect to the categorical variables(i.e., science teachers)

\begin{tabular}{|c|c|}
\hline Categorical \& Independent Variables & Major and Dependent Variable \\
\hline Gender(levels: Male \&Female) & Self-awareness of the students \\
\hline Science Teaching (levels: with head\& with heart) & \\
\hline
\end{tabular}

\section{Tool}

One questionnaire for the Science Teachers was developed and standardized by the authors. It was used in the present study to find out whether the teacher teaches with head or with heart.

Another questionnaire, developed and standardized by the authors, was used for the present study to find out whether the students were self-aware or not.

\section{Sample}

Random sampling procedures were utilized for this study. The population of the study comprised all the science teachers (Physical Science, Life Science, and Mathematics) of different Government sponsored Bengali medium schools of the Kolkata city in West Bengal, India.

\section{Collection of data}

The authors had first made a list of the schools at the Kolkata city which appeared convenient for the study to be carried out. Then, from that list, 11 schools were randomly selected (i.e., 3 schools from North Kolkata and the rest from South Kolkata). The researcher selected and collected data from 460 students, out of who 45 were rejected from the analysis because they did not completely fill in the questionnaire that was used to collect the data. During analysis, the researcher had to eliminate further 10 students because they had very poor scores. Thus, the final sample size for the study comprised of 405 students.

School wise data were also collected from the students about their most favourite science teachers there, assuming that those teachers have the greatest influence over the students in developing their selfawareness. Then, relevant data were collected from the 65 science teachers of those sampled schools, out of which 7 were rejected from the final analysis because the data provided there were incomplete. Therefore, the final sample size for the study comprised of 58 science teachers [vide Table 2].

Through descriptive survey method the researcher investigated the impact of the methods employed by the science teachers for developing selfawareness among their students. After preparing the tools of the study, the researcher got engaged in collection of data. At first, the respected institutional heads of those schools which were selected randomly were contacted. Then the intended research work and purpose was informed to them for obtaining permission to conduct the survey. The science teachers were communicated through the head of the institutions. The purpose and significance of the study was explained to them. The science teachers were found willingly for data collection from the students and as such they also helped the researcher for fixing date, time and arrangement of the classes for her data collection. Data were collected from both the teachers and the students with the help of two different questionnaires by survey methods. The survey was developed to capture information regarding the development of student's self-awareness as well as the teacher's view on selfawareness. Participants were informed that all of their responses were confidential and anonymous. The science teachers and the students were requested to read the instructions carefully and to ask the researcher if they have any difficulty in understanding the instructions. The students and the science teachers were informed that they were free to express their responses as they feel and should select the right option only. Only the students were assigned specific time limit and it was emphasized that no item should be omitted. The students were again instructed to check for any unanswered items of the questionnaire. The responses of the teachers and the students were arranged properly. The incomplete questionnaires were discarded. Finally data scoring were done for all the completed questionnaires and the collected data were entered in the tables for their consequent analysis. 
Table 2: Table for gender wise and type of science teaching wise distribution of the sampled teachers

\begin{tabular}{|l|c|c|c|c|c|}
\hline \multicolumn{2}{|c|}{ Variables } & \multicolumn{2}{c|}{ Type of teaching } & \multirow{2}{*}{ Total } & \multirow{2}{*}{ Percentage } \\
\cline { 3 - 4 } & With head & With heart & & \\
\hline \multirow{2}{*}{ Gender } & Male & 5 & 30 & 35 & 60 \\
\cline { 2 - 4 } & Female & 8 & 15 & 23 & 40 \\
\hline \multicolumn{2}{|c|}{ Total } & 13 & 45 & \multicolumn{2}{|c}{58} \\
\hline \multicolumn{2}{|c|}{ Percentage } & 22 & 77.5 & & \\
\hline
\end{tabular}

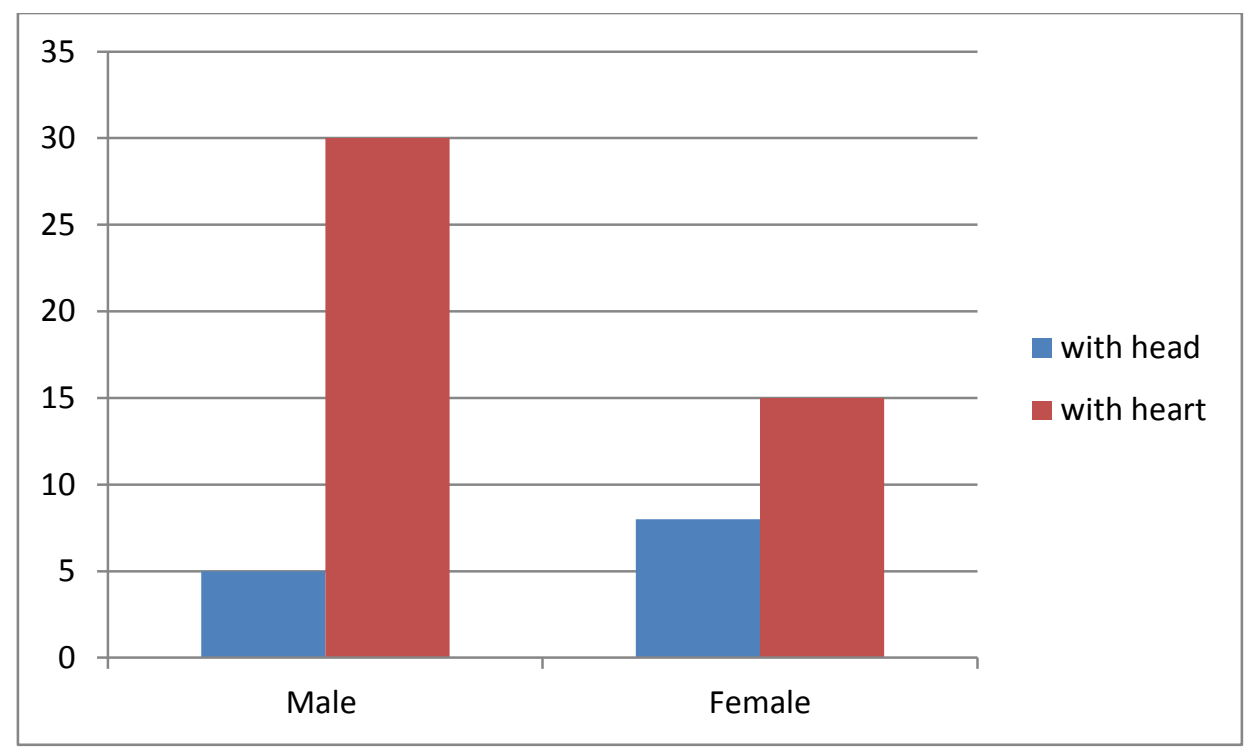

Fig-1 Graphical representation of Gender wise and Type of Teaching wise distribution of the sampled Teachers

From the Table 2 and Fig -1 it can be viewed science teachers. So there are total 58 science teachers that there are 35 male science teachers and 23 female taken for the present study.

\section{RESULTS}

Table-3:Tabular presentation of the descriptive and inferential statistics for testing the $\mathrm{H}_{0} 1$ :

\begin{tabular}{|c|c|c|c|c|c|c|c|c|}
\hline Variable & Levels & $\mathbf{N}$ & Mean & Std.Deviation & $\begin{array}{c}\text { Std.error } \\
\text { mean }\end{array}$ & $\mathbf{t}$ & $\mathbf{d f}$ & $\begin{array}{c}\text { Sig. } \\
(\mathbf{2} \text { tailed })\end{array}$ \\
\hline \multirow{2}{*}{ Teaching } & With head & 13 & 28.23 & 0.44 & 0.12 & $\mathbf{1 5 . 7 9 \#}$ & $\mathbf{5 6}$ & $\mathbf{2 . 7 9 E}-22$ \\
\cline { 2 - 9 } & With heart & 45 & 42.53 & 3.24 & 0.48 & & & \\
\hline
\end{tabular}

\#Significant at 0.05 level of significance. 


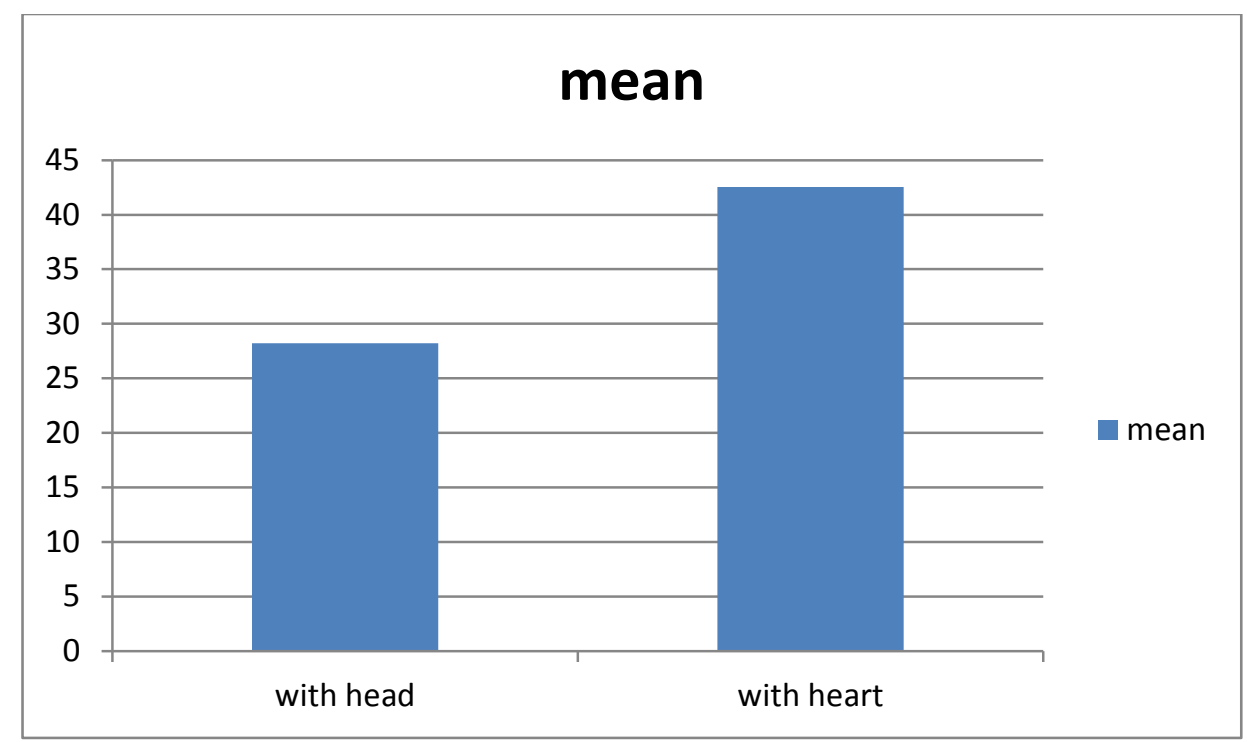

Fig-2: Graphical representation of data of table no-3

The analysis in Table-3 shows that in comparing the scores of the teachers teaching with heart and the teachers teaching with head, the calculated $\mathbf{t}_{(56)}$ value is 15.79 and ' $p$ ' value is $2.79 \mathrm{E}-22(\mathrm{p}<0.05)$. Hence, $t$ is significant at 0.05 level of significance. So $\mathbf{H}_{0} \mathbf{1}$ is rejected. Therefore, it can be said that there is a significant difference between the science teachers teaching with heart and the science teachers teaching with head in developing self-awareness among their students.

Fig 2 shows that the mean scores of the teachers teaching with heart are found to be higher than the teachers teaching with head.(teachers teaching with heart $=42.53$ and teachers teaching with head $=28.23$

Table-4: School wiselist of number of students obtaining high scores[ $\geq 80 \%]$ in relation to their most favourite science teachers' teaching with heart and teaching with head

\begin{tabular}{|c|c|c|}
\hline Sl.no. of school & $\begin{array}{c}\text { Most of the } \\
\text { favourite } \\
\text { science } \\
\text { teachers } \\
\text { teaching with }\end{array}$ & $\begin{array}{c}\text { Percentages of students obtaining high } \\
{[\geq 80 \%] \text { scores }}\end{array}$ \\
\hline 1 & Head & $35 \%$ \\
\hline 2 & Heart & $62 \%$ \\
\hline 3 & Heart & $68 \%$ \\
\hline 4 & Head & $26 \%$ \\
\hline 5 & Heart & $56 \%$ \\
\hline 6 & Heart & $61 \%$ \\
\hline 7 & Heart & $58 \%$ \\
\hline 8 & Head & $46 \%$ \\
\hline 9 & Head & $49 \%$ \\
\hline 10 & Heart & $55 \%$ \\
\hline 11 & Heart & $59 \%$ \\
\hline
\end{tabular}




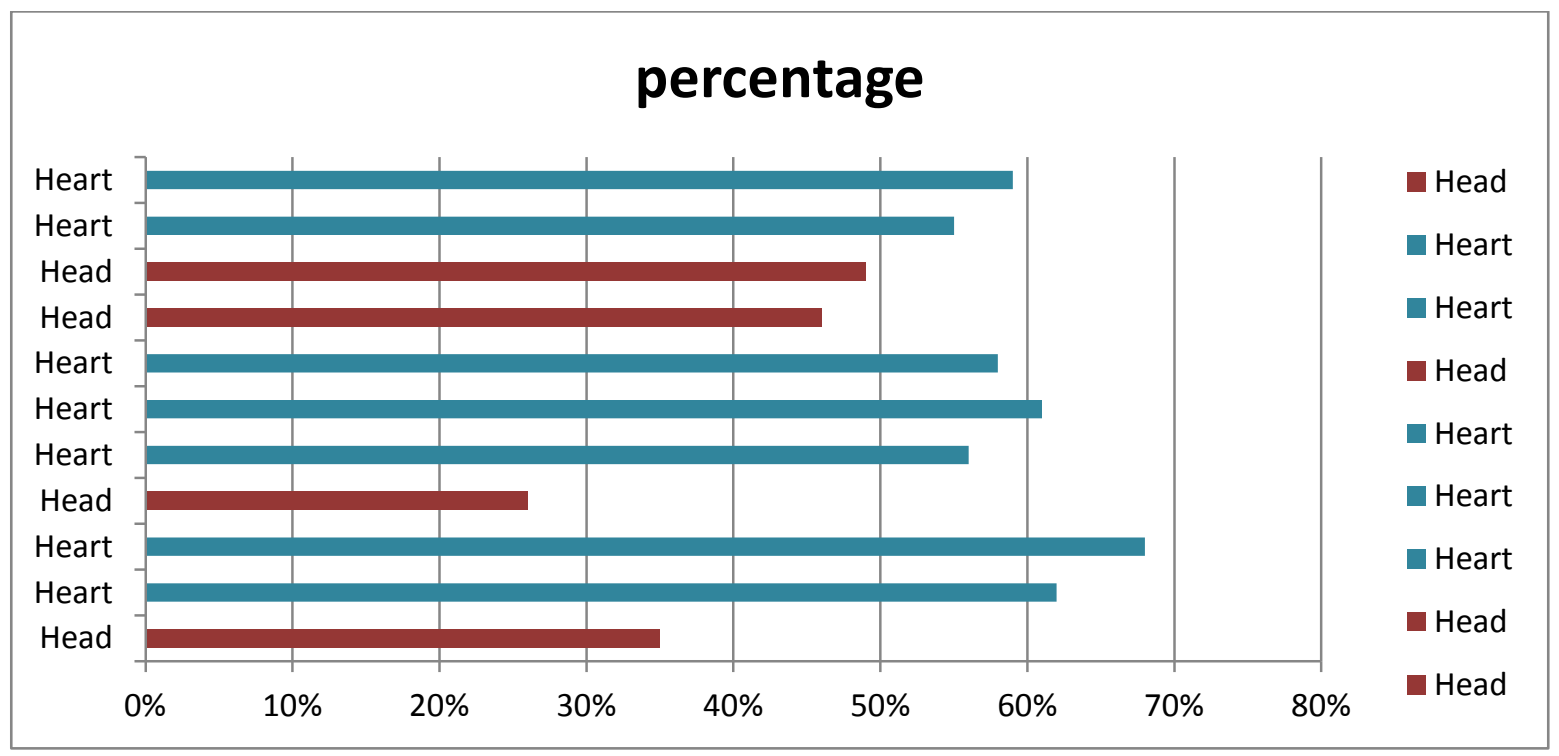

Fig-3:Graphical representation of table no-4

Table-4 shows that the students of the teacher, who teaches with heart has obtained higher score than the students of the teachers who teaches with head. So it supports the findings of table no 4 . Thus, the methods of developing self-awareness must be influenced by the characteristics of the teaching with heart.

Table-5 Tabular presentation of the descriptive and inferential statistics for testing the $\mathrm{H}_{0} 2$ :

\begin{tabular}{|c|c|c|c|c|c|c|c|c|}
\hline Variable & levels & $\mathbf{N}$ & Mean & Std.Deviation & $\begin{array}{c}\text { Std.error } \\
\text { mean }\end{array}$ & $\mathbf{t}$ & df & $\begin{array}{c}\text { Sig. } \\
\text { (2 tailed) }\end{array}$ \\
\hline \multirow{2}{*}{$\begin{array}{l}\text { Type of } \\
\text { Teaching of } \\
\text { Male } \\
\text { Science } \\
\text { Teachers }\end{array}$} & $\begin{array}{l}\text { Teaching } \\
\text { with head }\end{array}$ & 5 & 36.8 & 7.85 & 3.51 & \multirow[b]{2}{*}{$0.49^{\#}$} & \multirow[b]{2}{*}{33} & \multirow[b]{2}{*}{0.62} \\
\hline & $\begin{array}{c}\text { Teaching } \\
\text { with heart }\end{array}$ & 30 & 38.43 & 6.64 & 1.21 & & & \\
\hline
\end{tabular}

\#Not significant at 0.05 level of significance. 


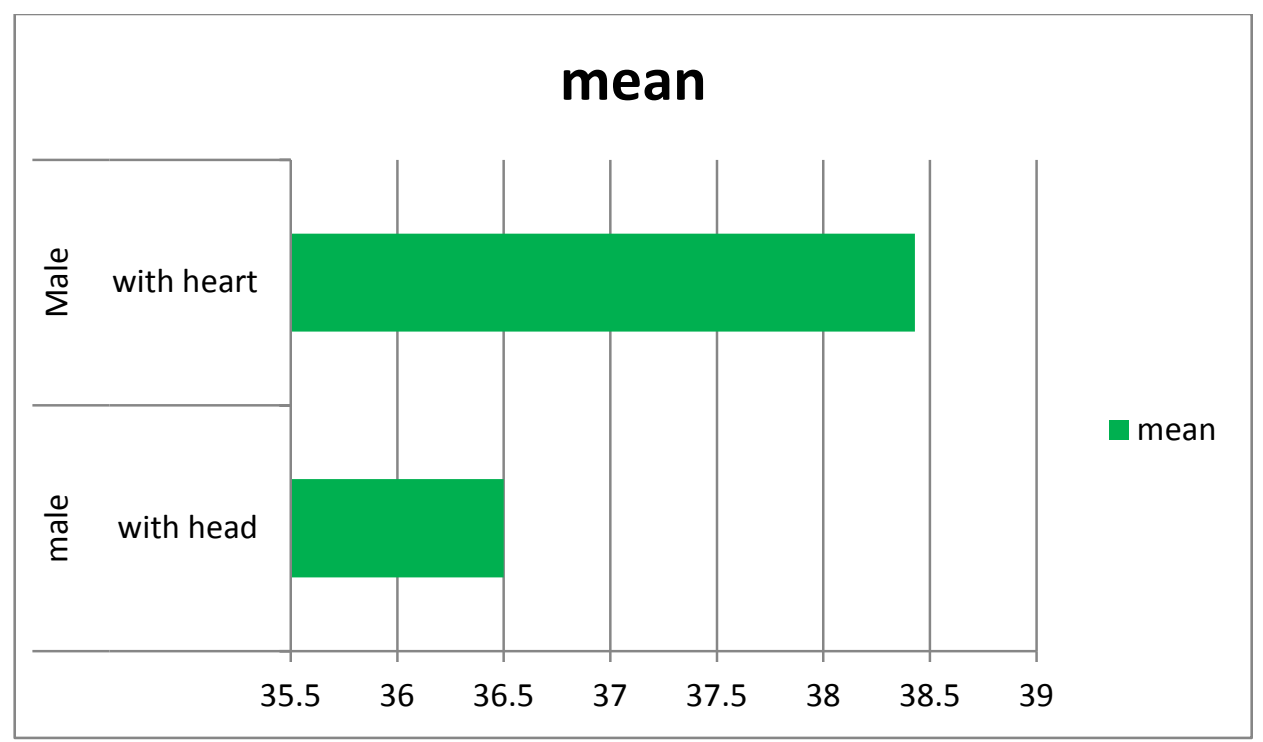

Fig-4: Graphical representation of the mean scores of the male science teachers who teaches with heart and the male science teachers who teaches with head

Fig 4. shows that the mean scores of the male science teachers teaching with heart are found to be higher than the male science teachers teaching with head.(teachers teaching with heart $=38.43$ and teachers teaching with head $=36.8$ )

The analysis in Table-5 shows that in comparing the scores of the male science teachers teaching with head and the male science teachers teaching with heart, the calculated $\mathbf{t}_{(33)}$ value is 0.49 and ' $p$ ' value is 0.62 $(\mathrm{p}>0.05)$. Hence $\mathrm{t}$ is not significant at 0.05 level of significance. So $\mathbf{H}_{0} 2$ is not rejected and it can be said that there is no significant difference between the male science teachers teaching with the head and the male science teachers teaching with heart in developing selfawareness among their students.

Table- 6 Tabular representation of the descriptive and inferential statistics for testing the $\mathrm{H}_{0} 3$ :

\begin{tabular}{|c|c|c|c|c|c|c|c|c|}
\hline Variable & levels & $\mathbf{N}$ & Mean & Std.Deviation & $\begin{array}{c}\text { Std.error } \\
\text { mean }\end{array}$ & t & $\begin{array}{c}\text { df } \\
\text { (2 tailed) }\end{array}$ \\
\hline $\begin{array}{c}\text { Type of } \\
\text { Teaching of } \\
\text { Female } \\
\text { Science } \\
\text { Teachers }\end{array}$ & $\begin{array}{c}\text { Teaching } \\
\text { with head }\end{array}$ & 8 & 35.75 & 7.96 & 2.81 & & & \\
\cline { 2 - 7 } weaching & 15 & 38.53 & 6.62 & 1.71 & $\mathbf{0 . 8 9}$ & & $\mathbf{2 1}$ & $\mathbf{0 . 3 8}$ \\
\hline
\end{tabular}

\#Not significant at 0.05 level of significance. 


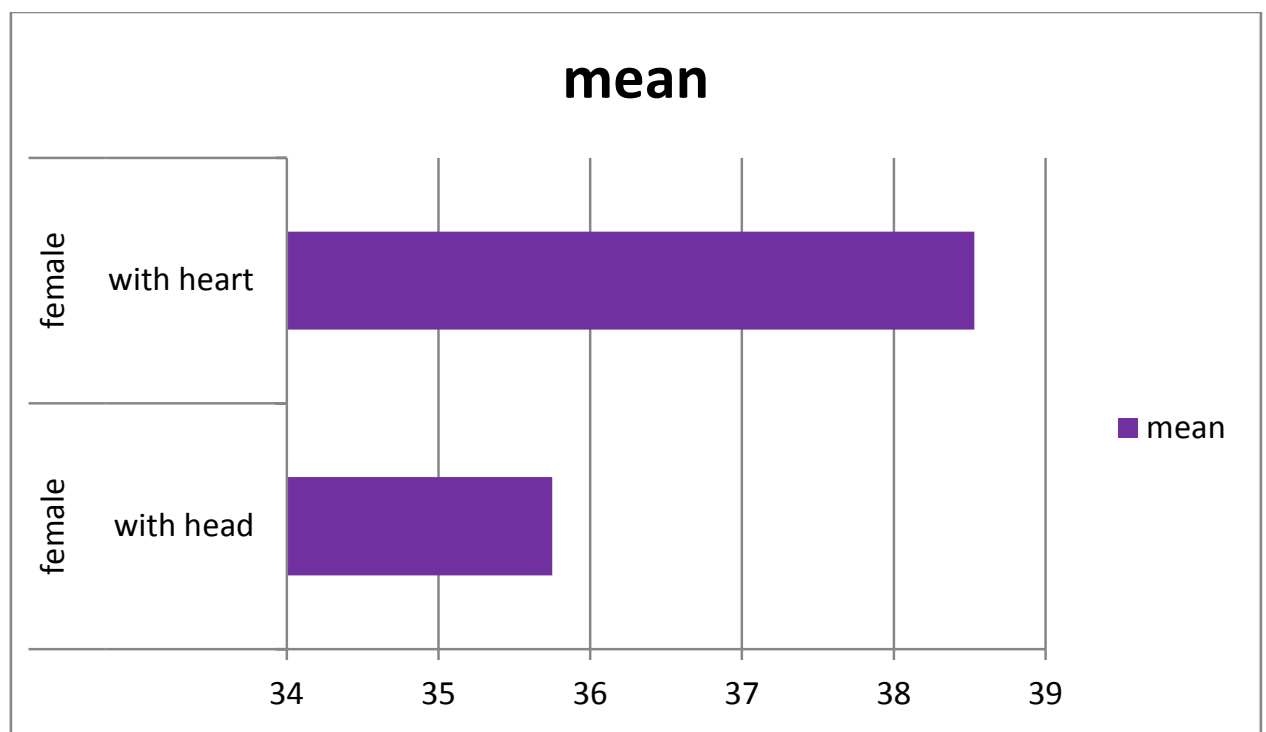

Fig-5: Graphical representation of the mean scores of the female science teachers who teaches with heart and the female science teachers who teaches with head

Fig 5 shows that the mean scores of the the mean scores of the female science teachers teaching with heart are found to be higher than the female science teachers teaching with head.(teachers teaching with heart=38.53 and teachers teaching with head $=35.75$ )

The analysis in Table- 6 shows that in comparing the scores of the female science teachers teaching with head and the female science teachers teaching with heart, the calculated $\mathbf{t}_{(21)}$ value is 0.89 and 'p' value is $0.38(p>0.05)$. Hence $t$ is not significant at 0.05 level of significance. So $\mathbf{H}_{0} 3$ is not rejected and it can be said that there is no significant difference between the female science teachers teaching with the head and the female science teachers teaching with heart in developing self-awareness among their students.

\section{MAJOR FINDINGS}

The results show that there is a significant difference between the teachers teaching with the heart and the teachers teaching with the head in developing self-awareness among their students. The mean score (i.e., 42.53) of the teachers teaching with heart is found to be higher than the mean score (i.e., 28.23) of the teachers teaching with head.

The findings also show that whatever be the subject of teaching, the students of the teachers, who teach with the heart have obtained higher scores than the students of the teachers who teach with head. Thus, the methods of developing self-awareness must be influenced by the characteristics of the teaching with emotion.
It can be said that there is no significant difference between the male science teachers teaching with the head and the male science teachers teaching with heart in developing self-awareness among their students.

It can also be said that there is no significant difference between the female science teachers teaching with the head and the female science teachers teaching with heart in developing self-awareness among their students.

\section{Educational implications of the study}

The educational implications of this particular study are further discussed in the following paragraphs to highlight its significant contribution to the field of research in teacher education and also in the learning environment of a school.

The present study is very much important because it deals with the students of the adolescent stage. The teachers need to understand the emotional turmoil that their students go through at this stage. The findings of this study may help them to comprehend the students'need to provide a conducive, comfortable and healthier psychological climate significant in theclassroom. It might facilitate the teachers to realize that providing the right and most favourable class environment to the students can improve their selfawareness and enhance their achievement in their day to day life. The study may enable teachers to understand the need to develop a strong emotional attachment with their students and offer them opportunities to freely express their feelings. 
It may also help the teachers to understand the necessity and importance of developing self-awareness among their students. The study might make the teachers realize the importance of identifying a lack of self-awareness in their students and the necessity to take steps to itsconsequent development.

This, in turn, may enable the teachers to provide a better classroom environment to take care of the mental well-being, recognition of cognitive, social and emotional intelligence of the students and to help them enhance their self-determination, independent thinking, and high-level processes. This may help the students to manage their huge stress in this complex society and make them capable to manage interpersonal and intrapersonal relations with themselves and others.

The study may further help to facilitate the students to be aware of the fact thatit is very important to be self-aware and due to inexperience, they are generally unable to realize its absence in themselves. Here lies the responsibility of the teacher to support students to reflect on their self-awareness. This may help the students to identify their level of selfawareness and modify it. Furthermore, the students may understand that developing self-awareness can lead them towards improved academic achievements and may enable them to become better human beings.

Last but not the least, the results of the present study would help to add further knowledge to the existing literature on the development of self-awareness among adolescent students.

\section{CONCLUSIONS}

To conclude, it can be said that the present study thus may help the teachers and students to search deeper into the factors which might affect the selfawareness of the students. The findings of this study strongly recommend that the teachers must provide care, affection, respect, supports and encouragement to their students for the proper development of their selfawareness. The development of self-awareness is very important because it includes the recognition of cognitive and social as well as emotional intelligence within the self. A teacher should be aware of the fact that the students and their influences always help a teacher to become a more self-aware, emotionally intelligent person. On the other hand, an emotionally balanced and self-aware teacher can keep a fruitful impression on his/her students' minds. So by the proper development of self-awareness, a teacher can assist the students to blossom into an emotionally and socially adjusted better human being with confidence, positive mental health, integrated and harmonious personality. This will have the immense potentiality to provide the nation with more responsible and contributing citizens of tomorrow.

\section{REFERENCES}

\section{Journals}

1. Chamanlal,M.J.(2014). Role of Computer Application \& Tools in the Scientific Research Process. International Journal of Research in Science \& Technology. 3(V): 33-40.

2. Dobrescu,A. (2013). Adolescent Self-esteem. Bulletin of the Transilvania University of Braşov, Series VII: Social Sciences. Law. 6 (55):139-144.

3. Fontaine, R. \&Oziev, G. (2013).Developing Selfawareness among students:An Islamic Perspective. European Scientific Journal.

1(December).Retrieved from eujournal.org.

4. Galleno, L. \&Liscano, M. (2013). Revitalizing the self:Assessing the relationship between selfawareness and orientation to change. International Journal of Humanities \& Social Science. 3(16):6271

5. Jayashree,V.(2011).Self-awareness: The starting point of change in individuals - An Empirical Analysis. Journal of Contemporary Research in Management. July-September. Retrieved from www.pigsm.ac.in

6. Jesu Prakash, M. \&Vasimalairaja, M.(2015). Selfawareness and Self-motivation have stimulus on the academic concert of XI standard pupils in Biology subject.1(9):93-99.

7. Kenny. M, Griffiths J., Grossman J. (2005). Selfimage and parental attachment among late adolescents in Belize. Journal of Adolescence.28(5): 649-664.

8. M. Kalaiyarasan, \& Solomon, M.D.(2016). Importance of self-awareness in Adolescence-A Thematic Research Paper. IOSR Journal of Humanities and Social science(21). Retrieved from https:// www.iosrjournals.org

9. Morin, A.(2011). Self-Awareness Part 1: Definition, Measures, Effects, Functions, and Antecedents. Social and Personality Psychology Journal.5(10):807-823.

10. doi:10.1111/j

11. Osterman, K.F. and Kottkamp, R.B.(1993).Reflective Practice for Educators: Improving Schooling through Professional Development. Corwin Press, INC, A Sage Publication Company, Newbury Park, California. Retrieved from www.itlifejimbutnotasweknowit.org

12. Paul, B., Schuman, B. \& Davis, D.(1973).Selfawareness Testing for School of Social Work students at Portland State University.PDX scholar. Retrieved from https://core.ac.uk.

13. Prakash,J.M. \&Vasimalairaja, M.(2015). Selfawareness \& Self-motivation has stimulus on the Academic Concert of XI standard pupils in Biology Subject. Retrieved from www.ijseas.com 
14. Rasheed, S.P., (2015), Self-awareness as a Therapeutic tool for Nursel Client Relationship. International Journal of Caring Sciences. Retrieved from www.internationaljournalof caringsciences.org

15. Richardson,B.G..\& Shupe.,M.J.(2003). The importance of teacher self-awareness in working with emotional \& behavioral disorders., Teaching Exceptional Children.36(2):8-13. Retrieved from www.casenex.com

16. Rochat, P.(2003). Five Levels of Self-awareness as they unfold early in life. Science Direct.12:717-731. Retrieved from $w w w$.sciencedirect.com

17. Sandu, C.M., Panisoare, G. And Panisoara, I.O. (2015).Study on the development of self-awareness in teenagers. Procedia-Social and Behavioural Sciences.180:1656-1660.

18. Sauer, K.M. \& Mertens, W.G.(2012). The Test Assessment Questionnaire:A tool for student selfassessment after the midterm examination.14(2):93-97.

19. Silvia, Paul J., and Guido H. E. Gendolla. (2001). On Introspection and Self-Perception: Does SelfFocused Attention Enable Accurate SelfKnowledge? Review of General Psychology 5: 241269.

20. Vijayarani,K.(2016). Self Image and Big Five Factors of Personality of Prospective Teachers at Primary Level. Research Nebula. v: 57-61. doi: 10.22183/RN

\section{Books}

1. Koul,L.(2005).Methodology of Educational Research,(304-384).Vikas Publishing House Pvt Ltd.

2. Mangal,S.K., \& Mangal, S.(2015). Research Methodology in Behavioural Sciences, (pp.591631).PHI Learning Private Limited, Delhi.

3. Shing,A.K.(2017). Tests, Measurements and Research Methods in Behavioural Sciences.(507539).Bharati Bhawan Publisher and Distributors.

\section{Dissertations}

1. Brenner, B.R.(2003).A study of Self-awareness, Self-efficacy \& Sojourner Adjustment over time (Doctoral dissertation). Retrieved from www.drum.lib.umb.edu

2. Condon,R.J.(2011). The relationship between selfawareness and leadership: Extending Measurement\&Conceptualisation.(M.Sc.

Dissertation).Retrievedfrom https://ir.canterbury.ac.nz/bitstream/handle/10092/ 5185/thesis_fulltext.pdf; sequence $=2$

3. Mc Nair, R.L. (2004).Student Self-esteem and the Looking -glass Self-perception of Emotional Support, Role Models, and Academic Success on a Community College Campus( Doctoral dissertation).Retrieved from https:// lib.dr.iastate.edu/rtd

\section{Websites}

1. Gay, L.M.(1990).Research Design. Retrieved from https://uogenglishfiles.wonderpress.com

2. Importance of self-awareness among children. Retrieved from https://www.understood.org/en/

3. Improving your child's self-awareness skills. Retrieved from cdn2hubspot.net/hub/287778/file

4. Stark, s. \&Baumgartner, P.(2006). The why, what \& how of Self-awareness. Retrieved from www.performancecoaching.ca

5. Ways to improve your self-awareness. Retrieved from https://www.cleaverism.com 